
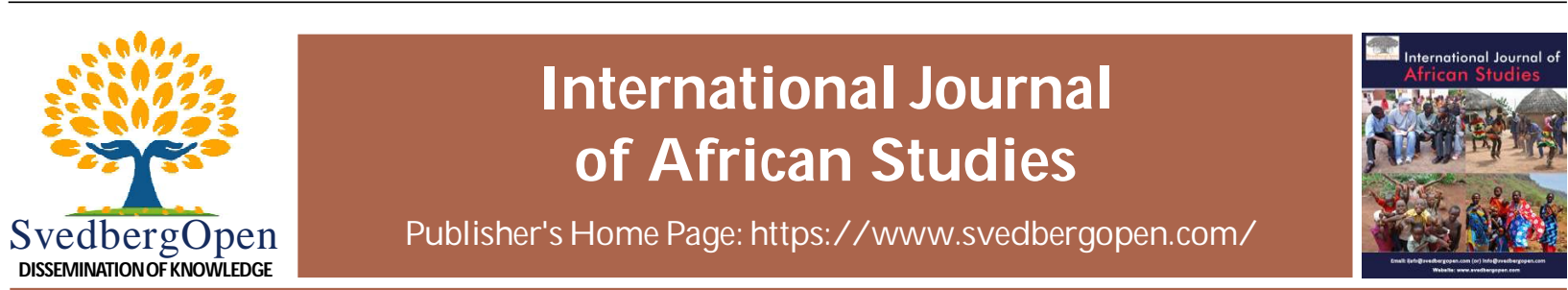

Research Paper

Open A ccess

\title{
Emotion and imagination: Perspectives in educational anthropology
}

Christoph Wulf $1^{*}$

${ }^{1}$ Free University of Berlin, Habelschwerdter Allee 45, Berlin 14195, Germany. E-mail: chrwulf@zedat.fu-berlin.de

\begin{tabular}{|c|c|}
\hline $\begin{array}{l}\text { Article Info } \\
\text { Volume 1, Issue 1, March 2021 } \\
\text { Received : } 07 \text { December } 2020 \\
\text { Accepted : } 17 \text { February } 2021 \\
\text { Published : } 05 \text { March 2021 } \\
\text { doi: 10.51483/IJAFRS.1.1.2021.45-53 }\end{array}$ & $\begin{array}{l}\text { Abstract } \\
\text { Although systems of education and socialization contribute to educating and socializing the } \\
\text { feelings of their addressees, little research is available to date regarding the norms according } \\
\text { to which this happens and, in particular, how this happens. In a nutshell, we could say that } \\
\text { all educational systems have implicit knowledge about how feelings are formed, and even } \\
\text { also practical knowledge about how feelings are, and should be, modeled in the various } \\
\text { institutions. In this context, an important role is played both by normative questions about } \\
\text { the aims, tasks and processes of the formation of emotions and by the practices of education } \\
\text { and socialization that are performed in the various institutions and that require empirical } \\
\text { investigation. This tension between the theoretical-reflexive investigation of normative } \\
\text { questions and the empirical study of institutional practices shapes emotion research in the } \\
\text { educational sciences. } \\
\text { Keywords: Emotions, Feelings, Upbringing, Education, Socialization } \\
\text { (O) 2021 International Journal of African Studies. This is an open access article under } \\
\text { the CC BY license (https://creativecommons.org/licenses/by/4.0/), which permits unrestricted } \\
\text { use, distribution, and reproduction in any medium, provided you give appropriate credit to the original } \\
\text { author(s) and the source, provide a link to the Creative Commons license, and indicate if changes were made. }\end{array}$ \\
\hline
\end{tabular}

\section{Introduction}

The formation of feelings takes place in a historical and cultural context. Their research is characterized by a double historicity and culturality. On the one hand it is a question of the historicity and culturality of the emotions that are to be researched and on the other it is important to consider the historicity and culturality of the emotion research itself. Considering this double historicity and culturality leads to educational research on emotions that has a historical and cultural basis becoming reflexive (Wulf, 2010, 2013a, 2013b).

For the investigation of emotions, diachronic research approaches, methods and procedures that take history into account and synchronic approaches focusing on difference in cultures play an important role. By creating difference, both perspectives help to understand and explain the particular and relational character of emotions. Therefore, it is essential that we consider historical examples and examples from foreign cultures in the discussion. The inclusion of historical examples and examples from foreign cultures often leads to historical and ethnographic methods being used to help to analyze the complexity of the emotions that are being studied. In the context of ethnographic research that does not focus on studying the formation of emotion in foreign cultures, but which also examines the formation of emotions in early childhood, school, peer groups, work, the media and religion as focused ethnographic investigations, it is important to take into account the situatedness, relationality and contextuality of emotions.

In contrast to the extensive experimental research into emotions, which is often at risk of addressing emotions as being independent of their historical and cultural contexts and of universalizing their results in a way that is not always

\footnotetext{
* Corresponding author:Christoph Wulf, Free University of Berlin, Habelschwerdter Allee 45, Berlin 14195, Germany..

E-mail: chrwulf@zedat.fu-berlin.de
} 
acceptable, the focus of anthropological and historical research as well as historical-anthropological research is on the particularity resulting from the situation, the relation and the context. In other words the focus is on the specific character of the emotions. Emotions are not understood as essence, nor as mere social and cultural constructions. Emotions have a bio-social character. From such an understanding of emotion a number of problems arise that require further exploration. These include the relationship between emotion and body, in particular between: emotion and movement, emotion and action, emotion and ritual, gesture and institution, emotion and memory, emotion and language, emotion and imagination.

While research into emotions is carried out intensively today, there is still very little research into the imagination and its significance for the development of emotions, for example (Wulf, 2021; Hüppauf and Wulf, 2009; Böhme, 2010). How emotions are related to imagination is a new question, the study of which gives rise to new insights for research into emotion and the study of imagination. An example of how emotions are generated by the imagination is Flaubert's Madame Bovary. When reading romantic novels, there arises in Madame Bovary the desire to experience the forms of love imagined in these texts and to realize them in her life. The novel shows that this desire is doomed to failure. In the experiencing of emotions, the imagination also plays an important role in less spectacular cases. For example, memories or anticipations of the future generated by the imagination can influence the quality and intensity of emotions. Before I pursue the mutual interdependence of emotion and imagination. I would like to develop a few reflections on the current state of cultural research into emotions and imagination.

Two contradicting approaches in the investigation of emotions can be distinguished today, both of which have an influence on the understanding of human emotionality. One tendency is based on the universal character of emotions, the other on their cultural diversity (Wulf, 2006a and 2016). According to the first view, all people have emotions and are similar in this. This is especially true for the basic emotions of joy, surprise, fear, anger, disgust and grief (Ekman, Sorenson and Ellsworth, 1982; Damasio 1999). According to the second view, the similarity in the biological foundations in the experience of basic emotions is not disputed. However, it is emphasized that the social and cultural shaping of emotions begins very early and is very long-lasting. That is why the idea that basic emotions are biologically given and are only culturally reshaped in retrospect falls short of the mark. Even if the biological foundations of human emotions are largely the same for all people, cultural and social differences in the experience of emotions can already be seen in their early ontogenesis. According to the current state of knowledge, one must therefore accept the bio-cultural character of the emotions (Röttger-Rössler and Markowitsch, 2009). In addition to the biological conditions, the following are important for the quality of emotions today: the globalization of societies and cultures, the special character of social and cultural communities and the specific events in the life of individual people. The intercultural character of the globalized world leads to new perspectives for research and understanding of human emotionality (Wulf et al., 2011b).

It was only in the last few years that the humanities, social and natural sciences began to research human emotions from an interdisciplinary and intercultural perspective. The changed situation in the world as a result of globalization was a prerequisite for this. It consists in the fact that today there are several equal centers of social and cultural development in the world. In the interdisciplinary and intercultural cooperation beyond the borders of these centers in South and North America, Asia, Africa and Europe, there is a growth in new forms and banks of knowledge.

\section{Emotions: historical perspectives}

Anyone who lives feels; anyone who does not feel is dead. Not the individual emotion, but the possibility of having emotions is a human condition. We have emotions, but at the same time these emotions constitute us so that we are the subject and object of our emotions. Emotions seize us. Although we can stimulate them, artificially generate or suppress them, we can also control how they are handled; but we cannot choose not to have emotions (Paragrana, 2009). There seem to be a limited number of basic emotions, but the shades, blends, and overlays between these emotions are many so that many emotions are not unambiguous (Kraus et al., 2017). Every time emotions are new, but also known at the same time; we know them, but not enough; much has been said about them, but no language can capture them fully; they surprise, cannot be tied down, change and evade control. Even in memory they appear differently. Emotions are fluid; that makes it difficult to make them objects of cognition; there is a difference that is hard to resolve between their dynamic movement and the claim to distanced objective knowledge.

Like the body, emotions are the subject of many sciences that have different concepts of emotion. A comparison between emotion psychology, psychoanalysis, cultural anthropology, literary, music and art studies, phenomenology and mentality research make this clear. Some studies investigate the biological aspects of emotions, others point to their social and historical character, to their societal and cultural character, and endeavor to explore these in everyday life. Whether, how, when and to what extent these perspectives can be interlaced is still a difficult question. 
Most ideas about emotions assume that emotions are located "inside" people, in the space-less place of the soul, but can be observed in people's behavior. According to this view, there is a difference between the material processes of the body and the immaterial processes of the soul, the emotions and the spirit of people, both of which, however, are not viable without the materiality of the body. Time and again, attempts have been made to overcome the hiatus between "outside" and "inside", which manifests itself in terms such as introjection and projection, defense and expression. With the help of signs that indicate the embodiment of mental processes or the somatization of mental processes, an attempt was made to bridge this hiatus. To this day, this is a central problem in research on emotions.

\section{Disembodiment versus physicality}

In a historical-anthropological analysis it can be shown that, despite some counter-movements, a disembodiment of emotions prevailed in Western cultures. It began with Plato. While in Homeric times emotions were understood as bodily powers that irresistibly seize and control people, these understanding changes in Plato's times. Emotions are no longer understood as mythical forces, but as something within people. The image of the charioteer in Phaedrus makes this clear. The individual is required to master his emotions. He should no longer be at their mercy; instead, he should curb and shape them. A hierarchization arises in which the physical is subordinated to the soul and spirit. Christianity intensifies this hierarchization further. It is the task of humans to control their emotions and to shape them according to moral criteria. The submission of emotions to the will of God or to the will of man is the task. The emotions should be subordinated to reason. The result is an intensification of the individualization and subjectification processes. A differentiated conscience arises, to which physicality and emotions have to "answer". With industrialization an acceleration of the disembodiment of emotions takes place. Distancing, disciplining, moralizing and abstraction are important aspects in this process, the different forms of which have been traced by Foucault (1977) and Elias (1978), among others.

Like the soul, emotions are often thought of as immaterial. The character of a breath, a pneuma, is ascribed to the soul; this goes hand in hand with their spiritualization, in which there is also a defense against death to which the material body is exposed, but which the immaterial, immortal soul overcomes. This understanding is illustrated by many depictions of the soul, in which the soul in the form of a small child floats into the sky when a person dies, while the body perishes (Kamper and Wulf, 1988; Jütteman et al., 2005; Wulf and Kamper, 2002). This disembodiment and despatialization of emotions has also triggered counter-movements.

Johann Gottfried Herder wrote in response to Descartes' cogito ergo sum: "I feel! I am" (Herder, 1960). Feeling is understood here as a guarantee of being, of human existence. For Herder, people experience themselves in feeling, in the immediate presence of feeling, of touching. Here the feeling derived from the sense of touch is the sense that determines the emotions. In the early $19^{\text {th }}$ century, there are many philosophical and literary examples of the tactile becoming the model of feeling. Since then, an essential approach to the world of emotions has been to explore how the subjects physically feel their emotions and to provide information about this. This presupposes the concept of a modern subject and implies the assumption of a wide range of individually diverging feelings. There is much evidence of this to be found in literature, such as novels and autobiographies, in pictures, music and films. The problem with these testimonies is that all individual sensations are expressed in a language that is collective property and in which there is only a limited possibility of specifying statements about emotions individually. Articulating this perspective, the subjective dimension, i.e., the first-person perspective of emotions does not mean that emotions can only be described subjectively. On the one hand, emotions are similar, on the other hand, they differ from person to person. Emotions are socially and culturally shaped, i.e. they are linguistically, medially and normatively incorporated and communicated. Many emotions are generated and conveyed in interactions; they are the result of relationships with other people and with the world.

\section{Sociocultural fields}

In many modern societies, emotions have taken on a new meaning. This can be seen in private family and love relationships, in interpersonal relationships, institutions, work relationships, the staging of politics and the new media. By outlining these societal, social and cultural areas, a frame of reference is created for researching the relationship between emotion and imagination.

\subsection{New media}

The staging and performance of emotions in the new media, such as in talk shows, on reality TV or in programs in which people in situations of disappointment, hurt, jealousy are shown to millions of viewers, is particularly striking (Kontopodis et al., 2017; Hill, 2005; Bignell, 2000). Many people seem to experience an intensification of their emotions by publicly expressing their intimate emotions and being seen by other people. The anonymous staging of emotions in Internet forums such as Facebook, Second Life, YouTube, Twitter, seems to help many people to feel emotions that they do not 
have, but would like to have. The worldwide media staging and broadcasting of catastrophes such as earthquakes, tsunami waves and hurricanes is accompanied by the display of intense feelings of suffering and pain that millions of viewers perceive with eerie feelings of pleasure (Gil and Wulf, 2015).

\section{Commercialization and politicization}

Emotions also play an important role in the workplace. Emotional intelligence and emotional competence are important prerequisites for successful cooperation. They are essential for decisions and management tasks. Dealing with emotions is also very important in marketing. The commercialization of emotions permeates all areas of human relationships in capitalist societies (Martin et al., 2003; Gobé, 2001). Not only commercialization, but also the politicization of emotions plays an important role in all societies and cultures. In particular where politics "becomes populist", they make use of emotions. In these cases politics play with people's fears and hopes (Furedi, 2005). In order to achieve political goals, emotions are manipulated against better understanding.

\subsection{Language and emotion}

Recent research on emotion has made it clear how important it is, from a cultural science perspective, not to isolate, reify and objectify emotions. Rather, one must be aware that emotions are not substances, but are connected to other human characteristics. Without body, consciousness, imagination and language there are no emotions; and these areas of the human being would not exist without emotions. In many cases, it is only the language that helps ensure that the relevant emotions can be developed and felt. An example of this is the rhetoric of romantic love. Without this rhetoric the ideas of romantic love would not have been able to establish themselves as a model for this form of love (de Rougemont, 1966). Another study shows how this feeling develops further under the conditions of capitalism (Illouz, 2018). The close connection between emotion and language can be demonstrated with another example. If there is a word in a culture that denotes a certain emotion, this emotion can also be detected in that culture. However, if this word is missing in another culture, then there is no emotion described by this word in this culture either. The Japanese "amae" is an example of this. If one tries to describe the emotion denoted by this word, one could say: "depend on the love of another person" or "surrender to the sweetness of another person". In order to understand the Japanese mentality, this word, which can hardly be translated into Western languages, is of central importance. The question is how far the feeling denoted by this word can be understood by people of another culture. Different positions are possible here. The first assumes that this feeling can also be understood by people from other cultures with the help of a linguistic description and the second position points out that this is only very inadequately possible, since it requires not only knowledge of the language, but also the incorporated relationships and actions denoted by this word. While the first position emphasizes the similarity in the emotional endowment of people, the second position refers to insurmountable cultural differences.

\section{Imagination}

Before we now sketch out some characteristics and properties that characterize emotions from a cultural and social science perspective and in which the imagination plays a central role, we will turn to what is meant by imagination (Wulf, 2021, 2014, 2013a; Hüppauf, and Wulf, 2009).

Despite different connotations, the Greek term fantasy, the Roman term "imagination" and the German term "Einbildungskraft" refer to a connection with the iconic in all three cases: fantasy is the force that makes the world appear; "imagination" and "Einbildungskraft" denote the creation of an inner world of images and ideas. Imagination, therefore, is the force that creates images, that expresses itself in images and that can be understood in images. In a general sense, "images" also include feelings, atmospheres and other "imaginations", that is sounds, traces of touch, smell and taste.

Imagination can be described as an energy with the help of which absent people, objects and feelings can be made present. In the imagination what is absent is present on the one hand; but on the other, it is also materially absent. The representative character of the imagination lies in this paradoxical structure. The representative power of imagination makes it possible to transform the outside world into the inside world and the inside world into the outside world. The spectrum of possible changes in this process ranges from minimal deviations to major innovations and inventions. While a psychoanalytic perspective, for example, tends to point to the limited possibilities of emotions changing, an aesthetic perspective emphasizes the creative possibilities of the individual. Perceptions of both the external world and internal images can generate emotions. An example of this is perceptions of erotic situations in the outside world or the perception of erotic images in the imagination. The erotic images of the imagination can precede and evoke emotions; they can become their medium and accompany them; but they can also be a consequence of emotions. Due to their mutual entanglement, it is not easy to distinguish what relation exists between emotion and imagination. 
The inner images that arise in the imagination, closely linked to emotions, differ from the images that arise in the perception of the outside world. In general, imaginary images do not achieve the sharpness and precision of perceptual images. Nevertheless, it is precisely the blurring of imaginary images that can cause great intensity (Wulf, 2021). The unreality of the images means that they are present, but at the same time also inaccessible. In contrast to the perceptual images that show the underlying objects from one perspective, imagined images are seen from several sides at the same time. In their case a single perspective can hardly be captured; the imagination supplements each perspective with another and thus conveys an overall picture. "The act of imagination is a magical act. It is an incantation, intended to make the object one thinks of, the thing one desires, appear in such a way that one can take possession of it" (Sartre, 2001). In relation to emotions this means: the act of imagination helps to visualize an emotion, to make it available to the consciousness, to make it appear in such a way that it can be visualized.

The imagination is rooted in the life of the human body. Arnold Gehlen sees its origin in the vegetative and understands it in connection with the excess drive of humans (Gehlen, 1988). For André Leroi-Gourhan, the development of the imagination has its starting point in the muscular activities in connection with movement, food and sex (Leroi-Gourhan, 1993). Marcel Jousse sees the emergence of the imagination in the mimetic actions of people directed towards the processes of nature (Jousse, 1974). Despite their different points of view, these authors agree that imagination is closely related to people's physical activities, emotions and actions.

The imagination is therefore an energy that has its origin in the physical and therefore in the unconscious, but which manifests itself in the form of images in the consciousness where it also conjures up emotions. It creates representations of emotions in the world of ideas and thereby creates an important prerequisite for the ability to communicate emotions. Imagination also brings emotions to light in dreams, visions and hallucinations and enables them to be created in works of culture, in art and literature, theater, music and architecture, as well as in politics, business and technology (Wulf, 2021).

The imagination not only brings emotions to the surface in images, thus making them accessible to consciousness. It can also dissolve emotions or change them through associating them with other emotions. Such a situation occurs, for example, in the anger we feel towards someone who offends us. By visualizing other emotions connected with our relationship with this person, the imagination can help to dissolve this anger or to align it with the ensemble of emotions we associate with this person and thereby relativize it.

While imagination and emotion are universal human conditions, historically and culturally they manifest themselves differently. They unfold differently under different historical and cultural conditions. Insofar as there are similarities between different epochs and cultures in how people live their lives, similarities in imaginations and emotions also develop. This creates "family resemblances" (Wittgenstein) with regard to the manifestations of imagination and emotion in otherwise very different historical periods and cultures, which make it possible to identify similarities.

\section{Anthropological characteristics of emotions}

In the following I would like to outline some characteristics and properties of emotions in which the imagination plays an important role.

\subsection{The flow of emotions}

Emotions arise in interactions with other people, in communication with them and in mimetic self-reference. Many emotions can be described as flowing (Csikszentmihalyi, 1990). Such a description implies that emotions change in everyday life. They overlap with previous emotions and form ensembles of emotions. In this process, the imagination plays an important role, which helps to select and update emotional dispositions and to superimpose different emotions. A special feature of human emotionality is constant moods and longer-lasting moods.

These influence how the emotions that arise in interactions are "tinted". When we are in a somewhat sad mood, we cannot really enjoy happy events either. Emotions determine our relationships with other people and the world around us. They are evaluative, i.e., they evaluate the events that have happened to us and make us act according to this evaluation. The emotional evaluation of the actions of other people and of events often takes place unconsciously or semi-consciously and is therefore only accessible to a limited extent in everyday life. This evaluating side of the emotions not only supports us in orienting ourselves in the world and towards other people. It helps us to make distinctions and to understand the meaning of situations, actions and contexts. Emotions help individuals and communities to develop sense and meaning and thereby make an important contribution to the identity of individuals and communities (Le Breton, 1998; Wulf and Kamper, 2002; Wulff, 2007; Greco and Stenner, 2008; Harding and Pribram, 2009). 


\subsection{Performativity and physicality}

Emotions are performative. With this thesis, there is a shift in attention. The focus is now less on understanding and interpreting emotions than on investigating and understanding how people express, represent, modify and control their emotions. From this perspective it is less important what people feel than how they feel (Wulf et al., 2011b). The focus of attention is the process in which, for example, people stage and perform their happiness. As a result, the forms of physical expression of emotions become the focus of attention. Physicality, habitualization, the dramatic composition of emotions become important. Gestures and rituals are of particular importance here (Wulf and Fischer-Lichte, 2010; Wulf et al., 2001, 2004, 2007, 2010, 2011a). This change in perspective is related to developments in modern societies that have led to us being societies where everything is put on stage. They are characterized by the fact that people's living space becomes a "small theater" in which one has to continuously display and market one's self. This tendency has also captured the emotions that we are expected to stage and perform accordingly (Wulf, 2005; Wulf and Zirfas, 2005). It is obvious that the innovative creative power of the imagination is needed for the staging of emotions.

\subsection{Emotions as cultural practices}

Such an expansion of perspective leads to understanding emotions as cultural practices, i.e., emotions are understood as actions and as part of practical knowledge (Kraus et al., 2017). Emotions can be understood as actions insofar as they have effects on other people. How this happens depends on the respective cultural values, norms and language and action games. This perspective leads to an understanding of actions which sees them as being more than just one activity. In many actions there are "passive" moments in which something happens to people that they did not intend and that they can only partially control and what makes them act. These passive and emotional elements make many actions possible that are wrongly interpreted as activity (Wulf 2006b; Paragrana 2009). An important example of actions in which "passio" and "actio" overlap are mimetic actions (Gebauer and Wulf ,1995; 1998 and 2003), in which the imagination enables mimetic reference.

\subsection{Emotional components in mimetic processes}

An emotional component is constitutive of many mimetic acts. This is because in mimetic action there is a reference to other people with the intention of feeling and imitating their actions, their nature. Those who act mimetically are so emotionally impressed by the actions of the other that they want to act like them. This creates an interweaving of passivity and activity that is characteristic of mimetic action. The person who mimetically relates to another person takes an "imprint" of the other person or their actions and emotional expressions and integrates them into their mental world, into their imaginary. This is done with the help of the imagination, which makes it possible for people to step out of themselves and into the world of another person. In early childhood, these processes are of particular importance for human development. When the imagination transgresses boundaries in this way, expressing and handling emotions, walking upright, speaking and social action are learned mimetically. Therefore, mimetic learning is the basic form of cultural learning, which is also of central importance for the development of emotionality in the course of processes of upbringing, education and socialization (Wulf, 2005; Gebauer and Wulf, 1995).

\subsection{Education and parenting}

Forming expression and dealing with emotions is of central importance in upbringing, education and socialization. These processes begin in the family and are continued in the educational institutions. The educational institutions also endeavor to impart emotional competence to the young generation, i.e., a competence with regard to dealing with their feelings, which enables them to live and cooperate with other people. With the help of their emotions, young people identify with society, its values, norms and goals. The education system is not only concerned with qualifications and the selection of young people. It is just as necessary to create ways of dealing with emotions with which young people will be able to find their way in their society and culture. This involves not only emotional adaptation, but also the emotional competence to take on conflicts in certain situations and to formulate criticism (Klika and Schubert, 2003; Zeitschrift für Erziehungswissenschaft, 2011; special issue Zeitschrift für Erziehungswissenschaft, 2012).

\subsection{Modeling emotions and gender}

No society, no culture leaves the formation of emotions to the individual. Education by parents, siblings and other people begins early in childhood. In the course of life, other educational institutions intervene in this process (Vandekerckhove et al., 2008). Added to this are the new media at an early stage and their increasingly important, still little researched influence on the emotionality of children and young people. In adolescence, the question of the gender character of emotions becomes important. How should young men, or young women, behave? Are there gender-specific 
behaviors? How do young men and women make a connection between the feelings they have in common and those that make them different? While there used to be clearly identifiable gender patterns in the emotions of men and women, many of them have lost their clarity and distinctiveness.

\subsection{Psychotherapeutic work with emotions}

In cases in which the formation of the emotions has not succeeded, psychotherapeutic work with and on the emotions is of growing importance. With the expansion of this area, developments are processed that are related to the modernization of society, the dissolution of traditional family ties, increasing individualization and the associated emotional problems. Many people are no longer able to cope with their emotions and need help. In modern societies, taking care of oneself and one's emotional well-being is becoming an increasingly important condition for the quality of individual and communal life and thus also for educational processes (Greenberg, 1997).

\section{References}

Bignell, Jonathan. (2000). Postmodern Media Culture. Edinburgh: Edinburgh University Press.

Böhme, Hartmut. (2010). Gefühl. In. Wulf, Christoph (ed.). Der Mensch und seine Kultur. Köln: Anaconda, 525-548.

Csikszentmihalyi, Mihaly. (1990). Flow: The Psychology of Optimal Experience. New York: Harper and Row.

de Rougemont, Denis. (1956/1966). Love in the Western World, trans., Montgomery Belgion, revised edition, reprint, New York: Fawcett.

Elias, Norbert. (1978). The Civilizing Process. New York: Urizen Books.

Ekman, Paul E., Sorenson, Richard, and Ellsworth, Paul. (1982). Emotions in the Human Face. New York: Pergamon.

Foucault, Michel. (1977). Discipline and Punish: The Birth of the Prison. New York: Pantheon Books.

Furedi, Frank. (2005). Politics of Fear. Beyond Left and Right. London and New York: Continuum Press.

Gebauer, Gunter, and Wulf, Christoph. (1995). Mimesis. Art, Culture, Society. Berkeley; University of California Press.

Gebauer, Gunter, and Wulf, Christoph. (1998). Spiel, Ritual, Geste. Mimetisches Handeln in der sozialen Welt. Reinbek: Rowohlt.

Gebauer, Gunter, and Wulf, Christoph. (2003). Mimetische Weltzugänge. Soziales Handeln, Ritualeund Spiele ästhetische Produktionen. Stuttgart: Kohlhammer.

Gehlen, Arnold. (1988). Man: His Nature and Place in the World. Trans. Clare McMillan and Karl Pillemer, with an introduction by Karl-Siegbert Rehberg. New York: Columbia University Press.

Gil, Isabel Capeloa, and Wulf, Christoph (eds.). (2015). Hazardous Future. Disaster, Representation and the Assessment of Risk. Berlin: de Gruyter.

Gobé, Marc. (2001). Emotional Branding. The New Paradigm of Connecting Brands to People. New York: Allworth.

Greco, Monica, and Stenner, Paul (eds). (2008). Emotions. A Social Science Reader. London and New York: Routledge.

Greenberg, Leslie. (1997). Working with Emotions in Psychotherapy. New York: Guilford.

Harding, Jennifer, and Pribram, E. Deirdre (eds.). (2009). Emotions: A Cultural Studies Reader. London and New York: Routledge.

Herder, Gottfried, Johann. (1960). Aus Herders Nachlass, edited by H. D. Irmscher. In: Euphorion. IV. Folge. 54. $281-204$.

Hill, Annette. (2005). Reality TV: Audiences and Popular Factual Entertainment. London: Routledge.

Hüppauf, Bernd, and Wulf, Christoph (eds) (2009). Dynamics and Performativity of Imagination: The Image between the Visible and the Invisible. New York: Routledge,

Illouz, Eva. (2018). Emotions as Commodities: How Commodities Became Authentic. London: Routledge.

Jousse, Marcel. (1974). L'anthropologie du geste. Paris: Gallimard.

Jütteman, Gerd, Sonntag, Michael, and Wulf, Christoph (Hrsg.). (2005). Die Seele. Ihre Geschichteim Abendland. Göttingen: Vandenhoek \&Ruprecht.

Kamper, Dietmar, and Wulf, Christoph (eds.). (1988). Die erloschene Seele. Berlin: Reimer.

Klika, Dorle, and Schubert, Volker (Hrsg.). (2003). Bildung und Gefühl. Hohengehren: Schneider. 
Kontopodis, Michael, Varvantakis, Christos, and Wulf, Christoph (eds.). (2017). Global Youth in Digital Trajectories. London et al.: Routledge.

Kraus, Anja, Budde, Jürgen, Hietzge, Maud, and Wulf, Christoph (eds.). (2017). Handbuch Schweigendes Wissen. Erziehung, Bildung, Sozialisation und Lernen. Weinheim, Basel: Beltz Juventa.

Le Breton, David. (1998). Les passions ordinaries. Anthropologie des émotions. Paris: Armand Colin.

Leroi-Gourhan, André. (1993). Gesture and Speech. Cambridge, Massachusetts \& London: MIT Press.

Martin Bill, Anleu, Sharyn Roach, and Zadoroznyj, Maria. (2003). Editor's Introduction to the Special Issue "Commercializing Emotions", Journal of Sociology 39, 331.

Paragrana. Internationale Zeitschrift für Historische Anthropologie, 18 (2009). 2. Schwerpunkt: Handlung und Leidenschaft. Jenseits von actio und passio. Hrsg. von Köpping, Klaus-Peter, Schnepel, Burkhard, \& Wulf, Christoph. Berlin: Akademie Verlag.

Röttger-Rössler, Birgitt, and Hans J. Markowitsch (eds.). (2009). Emotions as Bio-cultural Process. New York: Springer.

Sartre, Jean-Paul. (2001). The Psychology of the Imagination,. London: Routledge.

Vandekerckhove, Marie, von Scheve, Christian, Ismer, Sven, Jung, Susanne, and Stefanie Kronast (eds). (2008). Regulating Emotions. Culture, Social Necessity, and Biological Inheritance. Malden: Blackwell.

Wulf, Christoph. (2005). Zur Genese des Sozialen: Mimesis, Performativität, Ritual. Bielefeld: transcript.

Wulf, Christoph. (2006a). Anthropologie kultureller Vielfalt. Interkulturelle Bildung in Zeiten der Globalisierung. Bielefeld: transcript.

Wulf, Christoph. (2006b). Praxis. in: Theorizing Rituals. Issues, Topics, Approaches, Concepts, (eds.) Kreinath, Jens, Snoek, Jan, \& Stausberg. Michael. Leiden und Boston: Brill, 395-411.

Wulf, Christoph (ed.). (2010). Der Mensch und seine Kultur. Hundert Beiträge zur Geschichte, Gegenwart und Zukunft des menschlichen Lebens. Köln: Anaconda.

Wulf, Christoph. (2013a). Anthropology. A Continental Perspective. Chicago: Chicago University Press.

Wulf, Christoph (2013b). Das Rätsel des Humanen. Eine Einführung in die Historische Anthropologie. München: Wilhelm Fink.

Wulf, Christoph (ed.). (2016). Exploring Alterity in a Globalized World. London et al.: Routledge.

Wulf, Christoph. (2021). Human Beings and their Images. London: Bloomsbury.

Wulf, Christoph, Althans, Birgit, Audehm, Kathrin. Bausch, Constanze, Jörissen, Benjamin, Göhlich, Michael, Sting, Stephan, Tervooren, Anja, Wagner-Willi, Monika, and Zirfas, Jörg. (2001). Das Soziale als Ritual. Zur performativen Bedeutung von Gemeinschaft. Opladen: Leske \& Budrich.

Wulf, Christoph, Althans, Birgit, Audehm, Kathrin, Bausch, Constanze, Jörissen, Benjamin, Göhlich, Michael. Mattig, Ruprecht, Tervooren, Anja, Wagner-Willi, Monika, and Zirfas, Jörg. (2004). Bildung im Ritual. Schule, Familie, Jugend, Medien. Wiesbaden: Verlag für Sozialwissenschaften.

Wulf, Christoph, Althans, Birgit, Audehm, Kathrin, Blaschke, Gerald, Ferrin, Nino, Jörissen, Benjamin, Göhlich, Michael, Mattig, Ruprecht, Schinkel, Sebastian, Tervooren, Anja, Wagner-Willi, Monika, and Zirfas, Jörg. (2007). Lernkulturen im Umbruch. Rituelle Praktiken in Schule, Medien, Familie und Jugend. Wiesbaden: Verlag für Sozialwissenschaften.

Wulf, Christoph, Althans, Birgit, Audehm, Kathrin, Blaschke, Gerald, Ferrin, Nino, Kellermann, Ingrid, Mattig, Ruprecht, and Schinkel, Sebastian. (2011a). Die Geste in Erziehung, Bildung und Sozialisation. Ethnographische Feldstudien. Wiesbaden: VS.

Wulf, Christoph, Suzuki, Shoko, Zirfas, Jörg, /Kellermann, Ingrid, Inoue. Yoshitaka, Ono, Fumio, and Takenaka, Nanae. (2011b). Das Glück der Familie. Ethnographische Studien in Deutschland und Japan. Wiesbaden: Springer VS.

Wulf, Christoph, and Fischer-Lichte, Erika (eds.). (2010). Gesten. Inszenierung, Aufführung, Praktiken. München: Wilhelm Fink.

Wulf, Christoph, Göhlich, Michael, and Zirfas, Jörg (eds.). (2001). Grundlagen des Performativen. Eine Einführung in die Zusammenhänge von Sprache, Macht und Handeln. Weinheim and München: Juventa.

Wulf, Christoph, and Dietmar Kamper (Hrsg.). (2002). Logik und Leidenschaft. Berlin: Reimer. 
Wulf, Christoph, and Jörg Zirfas (eds.), (2005). Ikonologie des Performativen. München: Wilhelm Fink.

Wulf, Christoph, and Jörg Zirfas (eds.). (2007). Die Pädagogik des Performativen. Weinheim und Basel: Beltz.

Wulff, Helena (eds.) (2007). The Emotions. A Cultural Reader. New York and Oxford: Berg.

Zeitschrift für Erziehungswissenschaft (2010), 1. Schwerpunkt Emotionen. Hrsg. v. Christoph Wulf, \& Manfred Prenzel, 14 .

Zeitschrift für Erziehungswissenschaft (2012). Sonderhelft. Die Bildung der Gefühle. edited by Ute Frevert, \& Christoph Wulf.

Cite this article as: Christoph Wulf (2021). Emotion and imagination: Perspectives in educational anthropology. International Journal of A frican Studies. 1(1), 45-53. doi: 10.51483/ IJAFRS.1.1.2021.45-53. 